(C)2019. Media Gizi \& Kesehatan Masyarakat. Published by Universitas Airlangga.

This is an open access article under CC-BY-SA license

\title{
Hubungan ASI Eksklusif dengan Perkembangan Balita yang Memiliki Riwayat Berat Badan Lahir Rendah (BBLR) di Puskesmas Tanah Kali Kedinding Surabaya
}

\section{Relationship Between Exclusive Breastfeeding with Development of Toddlers Who Have Low Birth Weight History (LBW) in Puskesmas Tanah Kali Kedinding Surabaya}

\author{
Hasniyah Rizka Kumala ${ }^{1}$, Windhu Purnomo \\ ${ }^{1}$ Departemen Biostatistika dan Kependudukan ,Fakultas Kesehatan Masyarakat Universitas Airlangga
}

\begin{abstract}
ABSTRAK
Latar Belakang: Bayi dengan berat badan lahir rendah (BBLR) atau bayi yang lahir <2500g, memiliki perkembangan cenderung lebih lambat dibandingkan anak yang lahir dengan berat badan normal. Pada kasus BBLR sangat jarang diberikan ASI secara eksklusif karena keinginan ibu untuk menaikkan berat badan bayi secara cepat, sehingga diberikan makanan tambahan selain ASI. Balita dengan riwayat BBLR sangat beresiko mengalami gangguan tumbuh kembang.

Tujuan: Tujuan Penelitian ini adalah menganalisis apakah ada hubungan antara ASI ekslusif dengan perkembangan balita dengan riwayat BBLR di Puskesmas Tanah Kali Kedinding Kota Surabaya.

Metode: Jenis penelitian analitik observasional yang bersifat cross sectional. Populasi ibu yang memiliki bayi usia 12-36 bulan dengan riwayat Berat Badan Lahir Rendah sebanyak 34 responden, menggunakan tehnik simple random sampling ditemukan besar sampel 32 responden. Variabel independen ASI eksklusif, variabel dependen pertumbuhan. Pengumpulan data menggunakan kuesioner dan uji statistic menggunakan spearman.
\end{abstract}

Hasil: Hasil penelitian menunjukkan bahwa dari penghitungan menggunakan uji spearman diperoleh $\mathrm{p}=0,000$ yang berarti ada hubungan yang signifikan antara ASI eksklusif dengan perkembangan pada balita dengan riwayat BBLR.

Kesimpulan: Kesimpulan dari penelitian ini semakin bayi diberi ASI eksklusif maka perkembangan balita akan semakin baik.

Kata kunci: Air Susu Ibu (ASI) eksklusif, Tumbuh Kembang balita, Berat Badan Lahir Rendah (BBLR)

\section{ABSTRACT}

Background: Babies with Low Birth Weight or babies born $\leq 2500 \mathrm{gr}$, having a development of tend to be slower than children born with normal weight. In the case $L B W$ was given exclusive breastfeeding rarely because the mother want to raised the baby weight quickly, so given extra food other than breastfeeding. The growth of toddler with LBW history is very at risk of growth disorder.

Objective: The purpose of this study was to analyze the relationship between exclusive breastfeeding with development of toddlers who had LBW history in Puskesmas Tanah Kali Kedinding Surabaya The population involved the mother with a baby 12-36 months of age with a history of low birth weight as much as 34, respondents using simple technique random sampling found big 32 respondents.

Method: This research using cross sectional approach. The independent variable, exclusive breast milk the dependent variable growth and development. The collection of data using a questionnaire and test it statistic use spearman correlation.

Results: The results $p$ value of test spearman $p=0.000$ which means significant exists correlation between breastfeeding exclusively with development. 
Conclusion: The conclusion this study, the more babies are given exclusive breastfeeding, the better the toddler's development will be.

Keywords: exclusive breastfeeding, growth and development of toddler, Low Birth Weight (LBW)

Korespondensi :

Hasniyah.rizka.kumala-2017@ fkm.unair.ac.id

Hasniyah Rizka Kumala

Departemen Biostatistika dan Kependudukan, Fakultas Kesehatan Masyarakat, Universitas Airlangga

\section{PENDAHULUAN}

Masa emas atau golden age merupakan momen yang sangat penting bagi anak, karena pada saat tersebut terjadi periode kritis yang menentukan perkembangan anak selanjutnya. Orang tua bisa membentuk karakter pada usia ini karena $80 \%$ otak anak bekerja pada masa ini. Setiap orang tua pasti berkeinginan agar anaknya dapat berkembang secara optimal sehingga anak tersebut dapat mencapai tahap pertumbuhan dan perkembangan yang baik sesuai dengan potensi genetik balita itu.

Menurut Fenn, et al. (2004) Bila terjadi gangguan pertumbuhan pada masa emas sehingga pertumbuhan otak tidak terjadi sebagaimana mestinya, maka pertumbuhan tidak bisa dikejar pada periode berikutnya, sekalipun kebutuhan gizinya dipenuhi dengan baik dan anak tetap akan mengalami gangguan pertumbuhan otak. Hal ini akan memberi dampak sangat luas mulai dari kualitas bangsa, kecerdasan, dimensi ekonomi dan dimensi bangsa yang berefek pada masa depan anak.

ASI mengandung semua gizi penting yang diperlukan oleh bayi untuk tumbuh kembangnya (Prasetyono, 2012). Energi dari nutrisi yang dibutuhkan oleh bayi selama 6 bulan pertama seluruhnya terkandung dalam ASI, sehingga pedoman internasional menganjurkan pemberian ASI eksklusif selama 6 bulan pertama.

Terutama bayi dengan berat badan lahir rendah (BBLR) atau bayi yang lahir < 2500gr, memiliki pertumbuhan dan perkembangan cenderung lebih lambat dibandingkan anak yang lahir dengan berat badan normal. Pertumbuhan dan perkembangan balita dengan riwayat BBLR perlu terus dipantau. Hal tersebut untuk mencegah penurunan kemampuan intelektual dan produktivitas, peningkatan risiko penyakit degeneratif dan kelahiran bayi BBLR serta perkembangan di masa mendatang (Ningrum and Utami, 2017)

Berdasarkan data Riset Kesehatan Dasar (2018), proporsi berat badan anak lahir rendah pada balita di Provinsi Jawa Timur adalah 6,6 \%. Menurut data Dinas Kesehatan Kota Surabaya pada tahun 2018, presentase bayi berat badan lahir rendah di Kota Surabaya yaitu 2,14 \%. Salah satu puskesmas di Kota Surabaya yaitu Puskemas Tanah Kali Kedinding pada tahun 2015 bayi dengan berat badan lahir rendah (BBLR) sebesar 1,98 $\%$, tahun 2016 bayi dengan berat badan lahir rendah (BBLR) meningkat menjadi 3,18 \%, tahun 2017 terjadi peningkatan kembali menjadi 7,40\%.

Pada kasus bayi BBLR sangat jarang sekali diberikan ASI Eksklusif, hal tersebut di sebabkan rasa khawatir orang tua atau pengasuh terhadap berat badan bayi, orang tua lebih memilih untuk memberi makanan tambahan selain ASI untuk mempercepat kenaikan berat badan pada bayi. Bayi BBLR yang diberikan susu formula atau makanan sebelum berusia 6 bulan dapat lebih rentan terhadap penyakit, sehingga bayi akan mudah sakit. Hal ini didasarkan pada bukti ilmiah tentang manfaat ASI bagi daya tahan tubuh bayi, zat antibody pada ASI sangat bermanfaat untuk bayi. Selain itu ASI juga sangat bermanfaat bagi perkembangan otak anak.

Berdasarkan Riskesdas, 2018), angka pemberian ASI eksklusif pada bayi berumur 0-5 bulan di Indonesia hanya mencapai 37,3\% dan di Jawa Timur mencapai angka 54\%. Dari data Dinas Kesehatan Jawa Timur Kota Surabaya menyatakan bahwa selama tahun 2015-2017 Puskemasa Tanah Kali Kedinding mengalami penurunan jumlah cakupan ASI Eksklusif. Pada tahun 2015 presentase bayi yang diberi ASI Eksklusif usia 0-6 bulan adalah 71,49\%. Pada tahun 2016 presentase bayi yang diberi ASI Eksklusif usia 0-6 bulan mengalami penurunan yaitu 67,14\%. Pada tahun 2017 ASI Eksklusif masih mengalami penurunan yaitu 64,62 \%. Walaupun cakupan ASI Eksklusif tersebut masih termasuk baik, namun masih belum sesuai dengan target capaian ASI Eksklusif yaitu $80 \%$.

Anak dengan riwayat BBLR sangat beresiko mengalami gangguan tumbuh kembang, oleh karena itu perlu dikaji lebih dalam untuk memantau tumbuh kembang anak terutama yang memiliki riwayat BBLR.

\section{METODE}

Jenis penelitian yang digunakan penelitian analitik observasional. Penelitian observasional yang dilakukan terhadap sejumlah subjek menurut keadaan sebenarnya, tanpa ada intervensi dari peneliti. Rancangan penelitian yang digunakan dengan pendekatan Cross Sectional. Penelitian yang menekankan pada waktu pengukuran atau observasi data variable independen dan dependen hanya satu kali, pada satu saat, jadi tidak ada follow up. 
Populasi ibu yang memiliki bayi usia 12-36 bulan dengan riwayat Berat Badan Lahir Rendah sebanyak 34 responden, menggunakan tehnik simple random sampling ditemukan besar sampel 32 responden. Variabel independen ASI eksklusif, variabel dependen pertumbuhan dan perkembangan. Pengumpulan data menggunakan kuesioner dan uji statistic menggunakan mann whitney dan spearman.

Penelitian ini digunakan untuk mengetahui hubungan antara ASI eksklusif dengan tumbuh kembang balita usai 12-36 bulan dengan riwayat BBLR. Data hasil analisis yang didapatkan disajikan dalam beberapa tabel yang disertai dengan chart dan pembahasan secara mendetail.

\section{HASIL DAN PEMBAHASAN}

Distribusi frekuensi karakterisitik ibu balita yang berusia 12-36 bulan yang diperoleh dari hasil pengumpulan data yang dilakukan oleh peneliti dapat dilihat pada tabel berikut :

Tabel 1. Distribusi Karakteristik Ibu

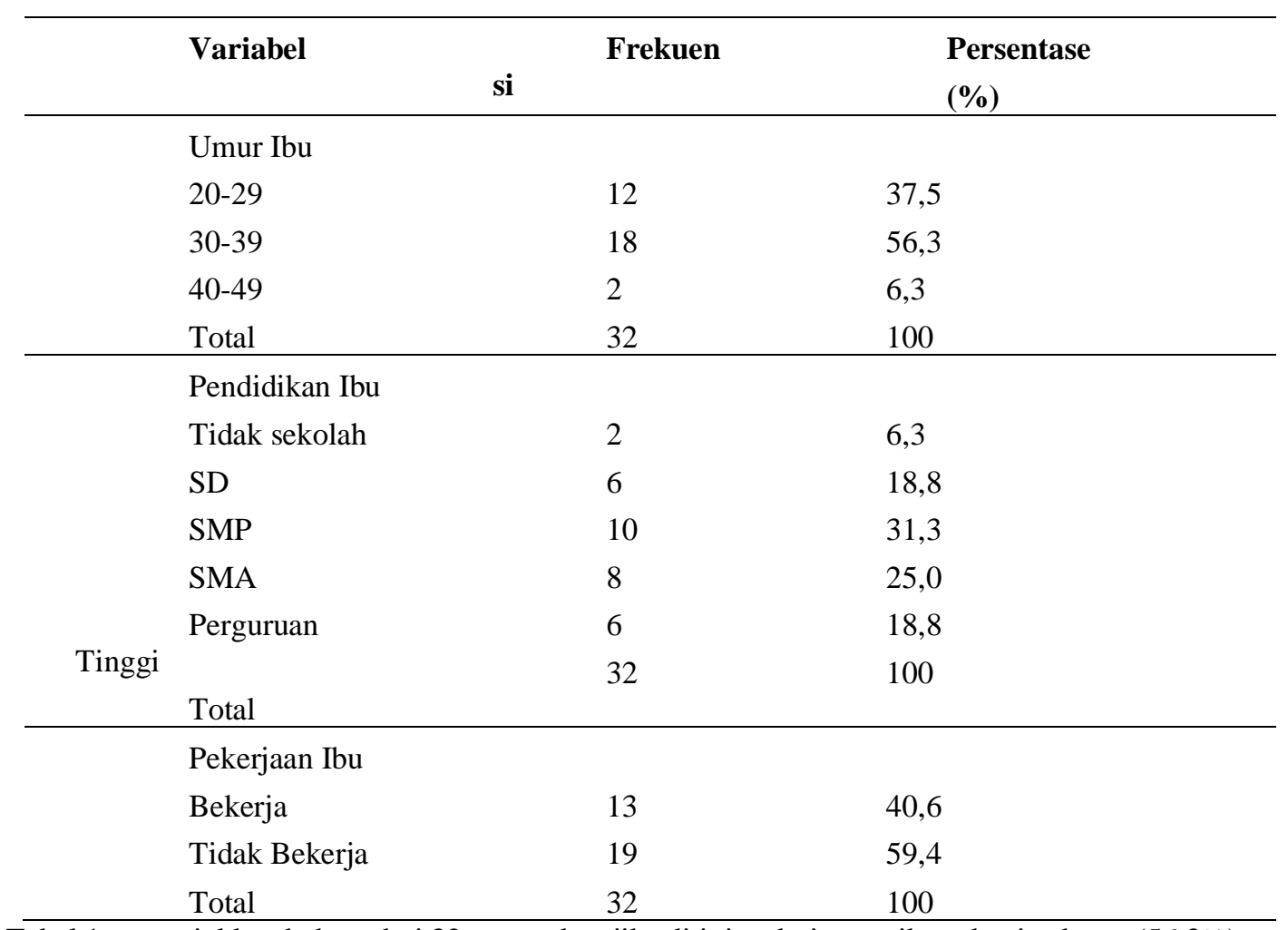

Tabel 1 menunjukkan bahwa dari 32 responden, jika ditinjau dari umur ibu sebagian besar (56,3\%) memiliki ibu yang berumur 30-39 tahun, jika ditinjau dari pendidikan ibu hampir sebagian besar (31,3\%) memiliki ibu dengan pendidikan terakhir SMP, sedangkan berdasarkan status pekerjaan Ibu sebagian besar $(59,4 \%)$ ibu tidak bekerja.

\section{Karakteristik Balita}

Distribusi frekuensi karakterisitik balita yang berusia 12-36 bulan yang diperoleh dari hasil pengumpulan data yang dilakukan oleh peneliti dapat dilihat pada tabel berikut:

Tabel 2. Distribusi Karakteristik Balita

\begin{tabular}{lll}
\hline Variabel & Frekuensi & Persentase $(\%)$ \\
\hline Jenis Kelamin & & \\
Laki-laki & 19 & 59,4 \\
Perempuan & 13 & 40,6 \\
Total & 32 & 100 \\
\hline Paritas & \\
1 & 18 & 56,3 \\
2 & 9 & 28,1 \\
3 & 4 & 12,5 \\
$\geq 4$ & 1 & 3,1 \\
Total & 32 & 100 \\
\hline
\end{tabular}


Tabel 2 menunjukkan bahwa dari 32 responden, jika ditinjau berdasarkan jenis kelamin balita sebagian besar $(59,4 \%)$ balita berjenis kelamin laki-laki, sedangkan jika ditinjau berdasarkan paritas sebagian besar 18 responden $(56,3 \%)$ balita adalah anak pertama.

\section{Pemberian Asi Eksklusif}

Distribusi frekuensi pemberian ASI Eksklusif pada balita yang berusia 12-36 bulan yang diperoleh dari hasil pengumpulan data yang dilakukan oleh peneliti dapat dilihat pada tabel berikut :

Tabel 3. Distribusi Pemberian Asi Eksklusif

\begin{tabular}{lccc}
\hline Variabel & Frekuensi & Persentase (\%) \\
& & & \\
\hline Tidak ASI Eksklusif & 16 & 50,0 & \\
ASI Predominan & 9 & 28,1 & \\
ASI Eksklusif & 7 & 21,9 & \\
\hline Total & 32 & \multicolumn{1}{c}{100,0} \\
\hline
\end{tabular}

Tabel 3 menunjukkan bahwa dari 32 responden sebagian besar (50\%) berstatus tidak ASI Eksklusif, hampir sebagian (28\%) diberikan ASI Predominan, dan sebagian kecil $(21,9 \%)$ yang di berikan ASI Eksklusif.

\section{Perkembangan Balita}

Hasil observasi penelitian mengenai perkembangan pada balita yang berusia 12-36 bulan dapat dilihat pada tabel berikut :

Tabel 4. Distribusi Perkembangan Balita Usia 12-36 Bulan

\begin{tabular}{lll}
\hline Variabel & Frekuensi & Persentase $(\%)$ \\
\hline Penyimpangan & 4 & 12,5 \\
Meragukan & 16 & 50,0 \\
Sesuai & 12 & 37,5 \\
Total & 32 & 100,0 \\
\hline
\end{tabular}

Tabel 4 menunjukkan bahwa dari 32 responden, hampir sebagian $(37,5 \%)$ mengalami perkembangan sesuai.

\section{Analisis Hubungan antara ASI Eksklusif dengan Perkembangan Balita Usia 12-36 Bulan yang Memiliki Riwayat Berat Badan Lahir Rendah.}

Untuk mengetahui hubungan antara ASI Eksklusif perkembangan balita usia 12-36 bulan yang memiliki riwayat BBLR di Wilayah Kerja Puskesmas Tanah Kali Kedinding didapatkan seperti tabel berikut:

Tabel 5. Tabulasi Silang Antara ASI Eksklusif dengan Perkembangan Balita Usia 12-36 Bulan yang Memiliki Riwayat Berat Badan Lahir Rendah di Wilayah Kerja Puskesmas Tanah Kali Kedinding, November 2019.

\begin{tabular}{lcccccc}
\hline \multirow{2}{*}{ Status ASI } & \multicolumn{3}{c}{ Perkembangan } & Total & $\mathrm{p}$ & $\mathrm{R}$ \\
\cline { 2 - 4 } & $\begin{array}{c}\text { Penyimpangan } \\
(\%)\end{array}$ & $\begin{array}{c}\text { Meragukan } \\
(\%)\end{array}$ & $\begin{array}{c}\text { Sesuai } \\
(\%)\end{array}$ & & \\
\hline Tidak ASI Eksklusif & $4(25,0)$ & $11(68,8)$ & $1(6,3)$ & $16(100)$ & \\
ASI Predominan & $0(00,0)$ & $3(33,3)$ & $6(66,7)$ & $9(100)$ & 0,000 & 0,644 \\
ASI Eksklusif & $0(00,0)$ & $2(28,6)$ & $5(71,4)$ & $7(100)$ & & \\
\hline Total & $4(12,5)$ & $16(50,0)$ & $12(37,5)$ & $32(100)$ & \\
\hline
\end{tabular}

*)Signifikan $(\mathrm{p}<0,05)$ Uji Spearman

Berdasarkan tabel 5 menunjukkan bahwa dari 32 responden, didapatkan 16 responden yang tidak ASI Eksklusif hanya sebagian kecil $(6,3 \%)$ yang mengalami perkembangan sesuai, dari 9 responden yang diberikan ASI Predominan sebagian besar $(66,7 \%)$ yang mengalami perkembangan sesuai dan 7 responden yang diberikan ASI Eksklusif sebagian besar $(71,4 \%)$ mengalami perkembangan sesuai. 
Setelah dilakukan penghitungan menggunakan uji Spearman didapatkan nilai p sebesar 0,000 dan jika dibandingkan dengan nilai $\alpha$ sebesar 0,05 maka nilai $\mathrm{p}<0,05$ yang berarti hasil uji signifikan, besar korelasi yang terjadi antara kedua variable adalah 0,644. Hasil uji statistic tersebut menunjukkan adanya hubungan antara ASI Eksklusif dengan Perkembangan Balita Usia 12-36 Bulan Yang Memiliki Riwayat Berat Badan Lahir Rendah. Semakin balita diberi ASI Eksklusif maka perkembangan semakin baik.

\section{Karakteristik Ibu dan Balita di Wilayah Kerja Tanah Kali Kedinding}

Setiap ibu sebagai orang yang paling dekat dengan balitanya harus memahami secara optimal tumbuh kembang anaknya. Tumbuh kembang adalah proses yang kontinu mulai sejak konsepsi sampai dewasa serta mempunyai ciri-ciri dan pola tertentu. Anak yang mengalami gangguan atau keterlambatan dalam tumbuh kembangnya akan beresiko untuk tahap kehidupan selanjutnya. (Soetjiningsih and Ranuh, 2015).

Pada penelitian ini menunjukkan bahwa umur ibu yang memiliki balita usia 12-36 bulan dengan riwayat Berat Badan Lahir Rendah mayoritas berusia 30-39 tahun, sedangkan berdasarkan pendidikan ibu terbanyak adalah pendidikan SMP, dan berdasarkan status pekerjaan ibu sebagian besar ibu tidak bekerja.

Menurut Unicef (2002), Umur yang baik bagi ibu untuk hamil adalah umur 20 - 35 tahun, karena pada umur yang kurang dari 20 tahun kondisi ibu masih dalam pertumbuhan, sehingga asupan makanan lebih banyak digunakan untuk mencukupi kebutuhan ibu. Pada umur diatas 35 tahun kondisi kesehatan ibu sudah mulai menurun dan rentan terhadap penyakit, sehingga penyakit tersebut dapat mengganggu peredaran darah ke plasenta dan mempengaruhi pertumbuhan dan perkembangan janin.

Menurut Soekanto (2005), menerangkan bahwa tingkat pendidikan seseorang dapat mempengaruhi pengetahuan sehingga terjadi perubahan perilaku yang positif. Tingkat pendidikan ibu memegang peran penting dalam membantu pertumbuhan dan perkembangan anak. Kemampuan ibu dalam menerima informasi dari luar terutama dalam mengamati anaknya jika terjadi kelainan atau gangguan kesehatan pada anak maka dapat segera diatasi, sehingga proses pertumbuhan dan perkembangan yang dialami oleh anaknya tidak terganggu.

Menurut Markum dalam buku Nursalam (2005) dijelaskan bekerja umumnya merupakan kegiatan yang menyita waktu untuk menunjang kehidupan dalam keluarga dimana ibu rumah tangga akan memiliki waktu yang lebih maksimal sehingga dapat mengetahui segala aktifitas anaknya. Orang tua yang tidak bekerja dapat memberikan stimulasi dengan baik karena ibu mempunyai banyak waktu untuk merawat bayinya termasuk memberikan stimulasi dengan frekuensi yang lebih intensif.

Ibu yang tidak bekerja mempunyai banyak waktu memberikan ASI secara eksklusif sehingga ibu dapat memantau pertumbuhan bayi dengan membawa bayi ke posyandu sehingga ibu dapat mengetahui kenaikan berat badan dan panjang badan, sedangkan ibu yang bekerja hanya sedikit mempunyai waktu untuk bayinya dan tidak sempat membawa bayinya ke posyandu sehingga ibu tidak dapat memantau pertumbuhan bayi. (Herlina, 2018)

Karakteristik balita pada penelitian ini jika ditinjau dari jenis kelamin maka sebagian besar balita berjenis kelamin laki-laki, sedangkan jika ditinjau berdasarkan paritas balita mayoritas anak pertama, dan jumlah balita yang paritas $\geq 4$ hanya sedikit. Hal ini menunjukkan bahwa program Keluarga Berencana yang bertujuan untuk membatasi/mengatur jumlah anak telah diterapkan dengan sangat baik di wilayah kerja Puskesmas Tanah Kali Kedinding.

\section{Pemberian ASI Eksklusif di Wilayah Kerja Puskesmas Tanah Kali Kedinding}

Berdasarkan status pemberian ASI Eksklusif pada balita dengan riwayat BBLR di Puskesmas Tanah Kali Kedinding ini menunjukkan bahwa mayoritas berstatus tidak ASI Eksklusif, dan hanya sebagian kecil saja yang berstatus ASI Eksklusif. Hal ini di karenakan banyaknya ibu yang beranggapan bahwa jika balita diberikan ASI saja tidak akan mencukup kebutuhan bayi terutama denga riwayat BBLR, pertambahan berat badan tidak terlalu banyak, sehingga ibu mengganti ASI dengan susu formula dan MPASI untuk mempercepat penambahan berat badan pada anak. Ibu beranggapan bahwa anak yang sehat adalah anak yang gemuk dan anak yang kurus itu tidak sehat.

Menurut Soetjiningsih (2014), ASI merupakan makanan terbaik untuk bayi karena dibutuhkan untuk kesehatan bayi dan mendukung pertumbuhan dan perkembangan bayi secara optimal. Bayi yang mendapatkan ASI eksklusif akan memperoleh semua kelebihan ASI serta terpenuhinya kebutuhan gizinya secara maksimal sehingga bayi lebih sehat, lebih tahan terhadap infeksi, tidak mudah terkena alergi, dan lebih jarang sakit karena ASI mengandung antibodi.

Anak yang memperoleh asupan gizi yang cukup akan dapat menunjang pertumbuhan yang normal. Menurut asumsi peneliti pertumbuhan seorang bayi harus diperhatikan apakah mengalami kenaikan berat badan atau tinggi badan, dengan pemberian ASI secara eksklusif akan dapat menunjang pertumbuhan bayi secara normal baik kenaikan berat badan dan tinggi badannya, karna ASI mengandung zat zat yang di butuhkan bayi selama masa pertumbuhannya 


\section{Pertumbuhan dan Perkembangan Balita Usia 12-36 Bulan di Wilayah Kerja Puskemas Tanah Kali Kedinding}

Pertumbuhan pada penelitian ini didapatkan hasil sebagian besar balita berusia 12-36 bulan dengan riwayat BBLR memiliki pertumbuhan baik, sedangkan yang lainnya mengalami pertumbuhan kurang. Hasil penelitian tersebut di dapatkan dari data Puskesmas Tanah Kali Kedinding. Pertumbuhan pada penelitian ini menggunakan 3 indikator yaitu $\mathrm{TB} / \mathrm{U}, \mathrm{BB} / \mathrm{U}$, dan $\mathrm{BB} / \mathrm{TB}$.

Perkembangan pada penelitian ini menunjukkan sebagian balita mengalami perkembangan yang meragukan. Hasil observasi ini didukung dengan nilai skoring KPSP balita yang menunjukkan bahwa masih banyaknya skor dengan jumlah rata- rata 7-8 yang berarti masih banyaknya balita dengan perkembangan meragukan dan tidak sesuai dengan usia mereka.

\section{Hubungan Pemberian ASI Eksklusif Terhadap Perkembangan Balita Usia 12-36 Bulan dengan Riwayat Berat Badan Lahir Rendah di Wilayah Kerja Puskesmas Tanah Kali Kedinding}

Hasil pada penelitian menunjukan bahwa adanya hubungan antara ASI Eksklusif dengan perkembangan balita usia 12-36 bulan dengan riwayat BBLR. Hal ini berarti ASI Eksklusif memiliki peran dalam menunjang perkembangan balita, semakin anak diberikan ASI eksklusif maka perkembangan anak juga akan semakin baik. Perkembangan yang di nilai dalam KPSP ada 4 aspek yaitu motorik kasar, motorik halus, bahasa, dan sosialisasi.

Sejalan dengan penelitian Aini dan Chundrayetti (2017), menyatakan bahwa anak yang memiliki riwayat ASI Eksklusif jika dibandingkan dengan anak yang tidak memiliki riwayat ASI Eksklusif terdapat perbedaan yang bermakna pada perkembangan menggunakan KPSP menurut umur, Hal ini menunjukkan bahwa perkembangan anak yang memiliki riwayat ASI Eksklusif masih lebih baik daripada yang tidak Eksklusif. Sama halnya dengan penelitian Andria, et al (2013) Menunjukkan bahwa terdapat perbedaan antara pemberian ASI eksklusif dan susu formula terhadap perkembangan bayi.

Kandungan Air Susu Ibu (ASI) mempunyai kandungan yang baik untuk perkembangan bayi antara lain taurin merupakan suatu bentuk zat putih telur yang hanya terdapat pada ASI berguna untuk neotransmitter yang berperan penting pada proses perkembangan otak dan retina, laktosa yaitu karbohidrat utama dalam ASI yang berfungsi sebagai sumber energi untuk kebutuhan tumbuh kembang bayi dan. lemak di ASI mengandung komponen asam lemak esensial yaitu asam linoleat dan asam alda linolenat yang akan diolah tubuh bayi menjadi AA dan DHA. ASI terdapat kadar lemak yang lebih tinggi dibandingkan susu formula (6:1). Kadar lemak yang tinggi dibutuhkan untuk mendukung perkembangan otak yang cepat semasa bayi. Arachidonic Acid (AA) dan Decosahexanoic Acid (DHA) adalah asam lemak tak jenuh rantai panjang (longchain polyunsaturated fatty acid) yang bukan hanya berfungsi untuk sumber energi, tetapi juga sangat penting bagi perkembangan sel - sel otak yang dapat mempengaruhi fungsi mental, penglihatan dan perkembangan psikomotorik bayi (Siagian dan Herlina, 2019).

Kandungan ASI sangat bermanfaat sebagai nutrisi makanan terlengkap yang merupakan kebutuhan asuh untuk bayi, pemberian ASI juga memberikan kekebalan tubuh, meningkatkan jalinan kasih sayang, dapat menunjang perkembangan motorik, menunjang perkembangan kepribadian, kecerdasan emosional, kematangan spiritual dan hubungan sosial yang baik. Hal ini dikarenakan pada saat menyusui, antara ibu dan bayi terjadi kontak fisik dan psikis sedini mungkin dengan ibunya, kebutuhan anak akan kasih sayang, diperhatikan dan dihargai memberikan rasa aman pada bayinya dan terjadi proses stimulasi yang merangsang terbentuknya kerjasama antar jaringan otak hingga menjadi lebih banyak dan terjalin sempurna sehingga dapat merangsang kemampuan dasar perkembangan bayi sejak dini, Ini terjadi melalui suara, tatapan mata, denyut jantung, elusan, pancaran dan rasa ASI (Khamzah, 2012).

\section{KESIMPULAN}

Dari hasil analisis dan pembahasan dalam penelitian yang berjudul "Hubungan Antara ASI Eksklusif dengan Tumbuh Kembang Balita Usia 12-36 Bulan dengan Riwayat Berat Badan lahir Rendah di Puskemas Tanah Kali Kedinding Kota Surabaya Tahun 2019” dapat disimpulkan bahwa :

Karakteristik ibu meliputi umur, pendidikan dan pekerjaan. Berdasarkan umur sebanyak 56,3\% ibu berumur 30-39 tahun, sedangkan pendidikan terakhir ibu 31,3\% adalah SMP, mayoritas 59,4\% ibu tidak bekerja. Karakteristik balita meliputi jenis kelamin dan paritas. Berdasarkan jenis kelamin balita 59,4\% adalah laki-laki. Jumlah paritas 56,3\% anak pertama.

Pemberian ASI eksklusif pada balita dengan riwayat BBLR di Puskesmas Tanah Kali Kedinding adalah sebesar 21,9\%.

Pertumbuhan balita $78 \%$ mengalami pertumbuhan baik dan berdasarkan perkembangan balita 37,5\% mengalami perkembangan sesuai.

Tidak ada hubungan antara ASI eksklusif dengan pertumbuhan balita usia 12-36 bulan dengan riwayat BBLR. Ada Hubungan antara ASI Eksklusif dengan perkembangan balita usia 12-36 bulan dengan riwayat BBLR. 


\section{ACKNOWLEDGEMENT}

Peneliti mengucapkan terimakasih kepeda seluruh responden yang telah mengijinkan peneliti untuk melakukan penelitian

\section{DAFTAR PUSTAKA}

Fenn, B., Morris, S.S. and Frost, C. (2004) 'Do childhood growth indicators in developing countries cluster? Implications for intervention strategies', Public Health Nutrition, 7(7), pp.829-834.

Prasetyono, D.S. (2012) 'Buku Pintar ASI Eksklusif (Pengenalan, Praktik dan Kemanfaatan-kemanfaatannya)'. Yogyakarta : DIVA Press

Ningrum, E.W. and Utami, T. (2017) 'Perbedaan Status Gizi Stunting Dan Perkembangan Antara Balita Riwayat BBLR dengan Balita Berat Lahir Normal', Jurnal Kesehatan Al Irsyad (JKA), 5(2), pp.46-56.

Balitbang (2018) 'Laporan Riset Kesehatan Dasar tahun 2018', Jakarta : Keementerian Kesehatan RI

Dinas Kesehatan (2015) 'Profil Dinas Kesehatan Kota Surabaya Tahun 2015'

Dinas Kesehatan (2016) 'Profil Dinas Kesehatan Kota Surabaya Tahun 2016'

Dinas Kesehatan (2017) 'Profil Dinas Kesehatan Kota Surabaya Tahun 2017'

Soekanto. S. (2005) 'Sosiologi Suatu Pengantar', Jakarta: Raja Grafindo Persada.

Soetjiningsih and Ranuh, G.I.G.N. (2015) 'Tumbuh Kembang Anak', Jakarta : EGC

Dinas Kesehatan (2018) 'Profil Dinas Kesehatan Kota Surabaya Tahun 2018'

Nursalam (2005) ‘Asuhan Keperawatan Bayi dan Anak', Jakarta : Salemba Medika.

Herlina, S. (2018) 'Tumbuh Kembang Bayi Yang Mendapatkan Asi Eksklusif Diwilayah Kerja Puskesmas Simpang Baru Kota Pekanbaru', Jurnal Kebidanan, 7(2), p. 166. doi: 10.26714/jk.7.2.2018.166-176.

Soetjiningsih. (2014) 'Tumbuh Kembang Anak', Jakarta: Penerbit Buku Kedokteran EGC.

Aini, N., Chundrayetti, E. and Susanti, R. (2017) 'Hubungan Riwayat Pola Pemberian ASI Eksklusif dengan Perkembangan Anak PraSekolah di Kecamatan Koto Tangah Kota Padang', Jurnal Kesehatan Andalas, 6(2), p. 295. doi: 10.25077/jka.v6.i2.p295-298.2017.

Andria, et al. (2013) 'Perbedaan Tumbuh Kembang Bayi Usia 6-12 Bulan yang Menggunakan ASI Eksklusif dengan yang menggunakan Susus Formula di Desa Sungai Sirih Kecamatan Singingi Kabupaten Kuantan Singingi Tahun 2013', Penelitian Dosen: Universitas Abdurrab.

Siagaian, DS., Herlina, S., (2019) 'Analisis Hubungan Pemberian ASI Eksklusif dan Pendidikan Ibu Terhadap Perkembangan Bayi', Jurnal Kesmas Asclepius (JKA), vol 1(2) Tahun 2019, DOI : https://doi.org/10.31539/jka.vli2.577

Khamzah, S N. (2012) ‘Segudang keajaiban ASI yang harus Anda Ketahui’, Yogyakarta : FlashBooks 